\title{
Mobil İletişim Çağında Kuşaklararası Koordinasyon Biçimleri
}

\author{
Sibel Onursoy (Doç. Dr.) \\ Anadolu Üniversitesi İletişim Bilimleri Fakültesi \\ sonursoy@anadolu.edu.tr \\ Orcid: 0000-0002-6414-0454
}

Başvuru Tarihi: 27.05.2018

Yayına Kabul Tarihi: 07.11.2018

Yayınlanma Tarihi: 21.01.2019

\section{Öz}

Mobil telefonlar zaman gözetmeksizin duygu ve sosyal iletişim için temel bir koordinasyon (mikro koordinasyon) sağlamaktadır. Hiper koordinasyon buna iki boyut daha katmaktadır. İlki mobil telefonun enstrümantal tesiridir. Mobil iletişimle vücut farklı bir mekânda bulunabilmektedir. Cep telefonu kullanımıyla bir tür entegrasyon oluşmakta, mobil iletişim sosyal hayatın içine farklı boyutlarda sızmaktadır. İkincisi ise grup içerisinde tartışma ve görüşme sırasında kendini sunmanın uygun biçimleri telefon yoluyla ortaya konmaktadır. Böylelikle hiper koordinasyon, telefonların aracılığı ve tesirinin yanı sıra sosyal ve duygusal etkileșimi kapsamaktadır. Bu çalışmada amaç, mobil iletişimin entegrasyonuyla sosyal hayatta yarattığı değişimleri sorgulamak, bu değişimleri koordinasyon, güvenlik ve etkileșim bağlamında farklı jenerasyonlarda değerlendirmektir. İnsanların cep telefonu gibi kișisel iletişim teknolojilerini nasıl kullandığı ve ne düşündügü konusundaki tutarlılık ve yenilikleri belirlemek, amaçlanan ve amaç dışına çıkan sonuçlarının neler olduğu belirlenmeye çalıșılmaktadır. Araştırmada nitel araștırma yöntemlerinden biri olan yarı yapılandırılmış derinlemesine görüşme tekniği kullanılmaktadır. Akıllı telefonlar iletişim tarzlarını ve yaygın olarak insanların davranışlarını değiştirmektedir ve sosyal yaşamda hayati bir organ görevini üstlenmektedir.

Anahtar Kelimeler: Mobil İletişim, Koordinasyon, Akıllı Telefon, Sosyal Değişim. 


\title{
Coordination Forms of Generations In Mobile Communication Era
}

\author{
Sibel Onursoy (Assoc. Prof. Dr.) \\ Anadolu University Faculty of Communication Sciences \\ sonursoy@anadolu.edu.tr \\ Orcid: 0000-0002-6414-0454
}

Date Received: 27.05 .2018

Date Accepted: 07.11.2018

Date Published: 21.01.2019

\begin{abstract}
Mobile phones provide a basic coordination (micro coordination) for emotional and social communication regardless of place and time. Hyper-coordination adds two more dimensions to it. The first is the expressive of mobile phone use. With mobile, the body can exist in a different place. There is some kind of integration with the use of mobile phones. Mobile communication is infiltrating into social life in different dimensions. Secondly, the appropriate forms of self-presenting are via mobile phone during conversation or discussion within the group. Thus, hyper-coordination involves the social and emotional interaction and the structure associated with them, as well as the instrumental and expressive nature of the phones. The aim of this study is to examine the changes that social communities have created through the integration of mobile communication and to evaluate these changes in different age groups in the context of coordination, security, and interaction. In this research, determine how people use personal communication technologies like smart phones, and to determine consistency and innovations about what users think, what their intended and out-of-purpose consequences are. Semi-structured in-depth interview technique is used in this research. Smartphones are changing the way people communicate and are widely changing the behavior of people, and they play a vital organ in social life.
\end{abstract}

Keywords: Mobile Communication, Coordination, Smartphone, Social Change. 


\section{Giriş}

1950'lerde televizyonların, 1990'larda internetin ortaya çıkışına benzer olarak, mobil telefonlar da içinde bulunduğumuz çağdaki iletişim teknolojisinin getirisi olarak ortaya çıkmıştır (Castells et al., 2007). Artık mobil abonelik dünya genelinde milyarlarla ifade edilmektedir (International Telecommunication Union, 2017). Mobil teknolojinin benimsenmesindeki ve kullanımındaki hız ve yaygınlık, benliğin yeni temsillerini ya da benlik sunumunu (Goffman, 1959) beriberinde getirmekte ve yeni sosyal bağlantı biçimlerinin oluşmasına, kamusal alanın özel kullanıma olanak sağlamakta ve buna benzer bir dizi toplumsal durumu etkilemektedir.

Mobil iletişim sistemleri sosyal grupların ve bireylerin ihtiyaç duyduğu doğrudan aktarıma; dünyevi koordinasyona izin vermektedir. $\mathrm{Bu}$ büyük bir işlev ve enstrümantal bir aktivitedir. Mobil ya da akıllı telefonların önemli bir yanı bu enstrümantal ya da araçsal koordinasyon farklılıklarına fırsat sağlamasıdır. Bu aktiviteler 'mikro' koordinasyonun çekirdeğini oluşturmaktadır. Yani mobil cihaz yer ve zaman gözetmeksizin, duygu ve sosyal iletişim için temel bir koordinasyon sağlamaktadır. 'Hiper' koordinasyon ile buna iki boyut daha katılmaktadır. Birincisi mobil telefon kullanımının tesiridir. İnsanlar sohbet, görüntülü sohbet, mesajlaşma, masum ve tatlı tebriklerden, belki pornografik imajlara uzanan geniş bir yelpazede iletişim kurabilmektedir. Görüntülü bağlantı ile artık beden farklı bir mekânda bulunabilmekte; bir tür bütünleșme oluşmaktadır. Başka bir deyişle mobil iletişim, sosyal hayatın içine farklı boyutlar sızdırmaktadır. İkincisi olarak telefon yoluyla kendini sunmanın uygun biçimleri, grup içerisinde tartışma ve görüşme sırasında ortaya konmaktadır. Yani mobil telefonlar kendini sunma biçimlerinin vücut bulduğu yer durumundadır. Özetle hiper koordinasyon, telefonların araç tesirinin yanı sıra sosyal ve duygusal etkileşimi ve bunlarla ilgili strüktürü kapsamaktadır.

\section{Teknoloji Uzantısı Kuşaklar}

Teknoloji ve toplum arasındaki dinamik ilişki içerisinde mobil telefonun yaygın şekilde benimsenmesi, teknolojik kullanımlardan kaynaklanan sosyal değişimler, iletişim ve koordinasyon gibi alanları etkilemektedir. Marshall McLuhan ve Manuel Castells gibi sosyal bilimcilerden yola çıkıldığında, geleneksel kitle iletişim araçları çağından yeni bir kişisel iletişim toplumuna geçiş sürecinde mobil iletişimden kaynaklanan toplumsal değișimlerin belirgin bir aşama olduğu düșünülebilir. McLuhan (1962, 1964), iletişim teknolojilerinin ve özelliklerinin, bilişselliği ve sosyal organizasyonu şekillendirdiğini belirtmiştir. Buna paralel olarak toplum, baskı teknolojisinin gelişmesiyle görsel devire girmiş; televizyon, radyo ve filmler de bu geçiși destekleyerek bir kitlesel çağa evrilmiştir. Bu durum McLuhan'ın ünlü "Araç mesajdır" savıyla sonuçlanmıştır.

Teknolojik gelişmeler, bireylerin gündelik yaşantılarında karşı karşıya kaldıkları zorluklara çözümler getirerek; iş yükünü azaltmak ve hayatın kolaylaşmasını sağlamaktadır. $\mathrm{Bu}$ noktada, bireylerin düşünmeye, üretmeye, yaratıcı yönlerini ortaya çıkarma konusuna daha çok zaman ayırmasıyla faydalı uğraşlara yönelmesi gerekirken; günümüzün teknolojik gelişmeleri, insanların teknolojinin esiri haline gelmelerine ve tembelliğe yol açmaktadır. Bookchin'e göre (1996), modern toplumlar teknolojiye öyle bağımlı hale gelmektedir ki; toplumun ilerlemesini sağlayan akılcılık geri planda kalmaktadır; "Teknoloji insanlığın bir uzantısı olmaktan çıkmış; insanlık teknolojinin bir uzantısı haline gelmiştir". 
Toplumlar homojen değildir. Aynı toplumda farklı jenerasyonlar mevcuttur ve hayat tarzına etki eden teknolojik yeniliklere adaptasyonlarına bağlı olarak bu jenerasyonlar farklı yașam biçimlerine sahiptir. Howe ve Strauss'un (1992) bu durumu kuşak teorisi olarak adlandırmaktadır. Bu teoriye göre X kuşağı 1960-70’li yıllarda doğan, meslekî kariyer sahibi olmayı önemseyen, eğitim almış, kitap okumak için zaman ayırmayan ancak film izlemeyi tercih eden, duygusal, kişisel bakımına önem veren, değişime açık olan, meslekî performansında başarıya odaklanmış kişiler olarak betimlenmiştir. Diğer taraftan Y kuşağı; 1980'ler ve sonrasında doğan, teknolojik yenilikleri deneyimlemiș, bilgisayar ve atari oyunlarıyla büyümüș, ergenlik döneminde cep telefonlarıyla tanışmış, sosyal yönü gelişmiş, iş ortamında ve mesai saatlerinde esnekliği benimseyen, kariyerden daha çok kendini ifade etmeye önem veren, karar alımında pasif değil aktif olmayı isteyen jenerasyondur (Howe ve Strauss, 1992). Bu teori, Hammill (2005) tarafından Z kuşağl eklenerek geliştirilmiştir. Z kuşağı, 2000 ve sonrasında doğmuş kişileri tanımlamaktadır. Bilgiye ulaşma kapasiteleri, teknolojinin getirdiği firsatlar sayesinde, çok daha yüksektir. Tabletler, akıllı telefonlar ve bilgisayarlar yaşamlarının bir parçasıdır. Daha erken yaşta eğitim gören Z kuşağı daha hızlı zihinsel gelişim göstermektedir. Bireycilikleri diğer nesillere göre daha kuvvetlidir. Sosyalleşme yollarının en belirgin olanı sosyal medyadır. Dijital çağın çocukları olan Z kuşağının aynı anda birden fazla konu ile ilgilenebilme yeteneklerinin olduğu varsayılmaktadır. Dijital çağın çocukları olan Z kuşağının aynı anda birden fazla konu ile ilgilenebilme yeteneklerinin olduğu varsayılmaktadır. Teknolojiyi diğer kuşaklara göre çok daha iyi kullanan Z kuşağı, giyilebilir ve taşınabilir teknoloji ürünlerini günlük hayatının bir parçası hâline getirmiștir (Senbir, 2004, 27-28; Williams, 2010, 12). Türkiye İstatistik Kurumu 2017 verilerine göre Türkiye nüfusunun yaklaşık dörtte birini $\mathrm{Z}$ kuşağı oluşturmaktadır (0-14 yaş aralığı: 19 milyon). Bu kuşak sosyal paylaşım ağlarını yeni toplumsallaşma ortamları olarak görmektedirler. Bireylerin arasındaki sosyalleşme göz önünde bulundurulduğunda; internet kullanıcılarının gerçek hayatta gerçekleștirdiklerini, sanal dünyaya taşımaları, yapılan sosyal aktivitenin gerçekliği ile sanallığı arasındaki ayrımı bulanıklaştırmaktadır. Sosyal paylaşım ağları, insanları adeta esir alarak sosyal çevrelerinde dahi sosyal ve çevrelerine yabancllaşmış bireyler haline getirmektedir (Karagülle, 2014, 4). Zamanının büyük çoğunluğunu sanal dünyada geçiren bireylerin, büyük çoğunluğu kontrol altına alamadıkları internet kullanımı nedeniyle, sosyal, mesleksel ve özel yaşamlarında sorun yaşamaktadır. İnternet bağımlılığı terimi genel olarak, internet karşısında geçirilen uzun zaman ve internet kullanmayı kontrol edememe gibi durumların ifade edilmesinde kullanılmaktadır (Leung, 2004; Simkova \& Cincera, 2004; Young, 2004).

Ülkemizde internet bağımlılığı problemi bu teknolojiye daha hâkim olan gençlerde ve çocuklarda daha fazla görülmektedir ve aileler bu sorunlar nedeniyle tedavi merkezlerinin arayışına girmeye başlamıștır (Bozkurt vd., 2016, 244). Özellikle çocuk ve gençlerin internet bağımlılığına yatkın olmaları, küresel bir sorun olarak belirmektedir. Bu grup oyun, sohbet ya da arkadaş çevresiyle iletişime geçmek maksadıyla yoğun bir biçimde sanal ortamlarda yer almaktadır. Çocuklar arasında internet kullanımının artması çoğu zaman aile içi ilişkilerin zayıflamasına ve bununla birlikte çocukların iletişim kurmak, sosyalleşmek maksadıyla internete girme eğiliminde oldukları ileri sürülmektedir. Yapılan araştırmalar, ebeveynleri çalışan çocukların, sosyalleşme yönünden zayıf kaldıkları için, bu ihtiyaçlarını internete girerek giderdiklerini göstermektedir (Bayraktutan, 2005). Türkiye'de internet 
bağımlılığı üzerine yapılan araştırmalara bakıldığında, yalnızlık düzeyindeki artış ile internet bağımlılığındaki artış arasında paralel bir ilişki olduğu görülmektedir. Esen ve Siyez (2011) çalışmalarında cinsiyet, akademik başarı, yalnızlık ve aileden alınan sosyal destek gibi değișkenlerin bireylerin internet bağımlılı̆̆ı üzerinde etkili olduğunu ileri sürmektedirler. Gerçek yaşamda kurulan ilişkilerin sanal ortamlara taşınmasının sonucunda, insanlar sanal topluluklar arasında yerini almaktadır. Bu yeni sosyalleşme mekanlarında tüm duygu ve düşünceler ikon ve işaretler yoluyla ifade edilmektedir. Yüz yüze iletişimin bir alternatifi olarak düşünülen sanal iletişimde kurulan ilişkiler, bireylerin gerçek yaşamdaki ilişkilere yabancılaşmasına neden olmaktadır. Ínsanlar artık, yüz yüze iletişim için harcadıkları zamandan daha fazlasını, mobil iletişim araçları ya da bilgisayarlar aracılığıyla gerçekleştirdikleri iletişim için harcamaktadırlar (Aktaş ve Çaycı, 2012, 6).

\section{Mobil İletişim ve Koordinasyon}

İletişimde gelişen teknoloji ile toplum manifestoları arasındaki ilişkide yalnızca mobil iletişim cihazlarının tarzında değil, aynı zamanda bunları nasıl kullanıldıkları konusunda da bir değişim ortaya çıkmaktadır (Campbell at all, 2008, 374). Ling ve Yttri'nin teknolojinin kullanım işlevi araştırmalarında (1999, 2002; Ling 2004), mobil telefon kullanımının bazı özel kategorileri kavramsallaştırılmaktadır. $\mathrm{Bu}$ kavramsallaşan kategorilerden ikisi; mikro ve hiper koordinasyon olmak üzere yeni koordinasyon formu olarak tasvir edilmektedir:

- Mikro koordinasyon, temel lojistiği koordine etmek, halihazırda sürmekte olan gezileri yönlendirmek, başkalarıyla "işin içinde iken" plan yapmak gibi cep telefonunun enstrümantal kullanımlarını kapsamaktadır.

- Hiper-koordinasyon, mobil iletişimin ilişkisel boyutlarını ve tesirini ifade etmektedir; örneğin sohbet, kısa mesaj ya da anlık görüntülü arama yoluyla aile üyelerini veya arkadaşları zaman zaman arayarak kontrol etmek gibi kullanımları kapsamaktadır (Campbell ve Park, 2008, 375; Ling, 2004; Ling ve Yttri, 1999, 2002).

Mikro ve hiper koordinasyon biçimleri, mobil iletişim araçlarının doğası gereği oluşmaktadır. Mikro koordinasyon durumunda, mobil telefonların bireysel kullanımına bağlı olarak yer ve zaman sınırlılıklarının üstesinden gelinmekte, planlar ve organizasyonlar esneklik kazanmaktadır (Ling, 2004). Yer ve zaman mobil iletişim vasıtasıyla kişiselleştirilmektedir. Yani bireyler, kişisel amaçları için başkalarıyla yer ve zaman koordinasyonunda mobil telefonlara güvendikleri için, yer ve zamanın anlamı değişmektedir. Castells vd. yer ve zamanın bu yeniden yapılanma sürecini 'mekân akışı' ve 'belirsiz zaman' olarak tanımlamaktadır. Onlara göre mekanlar, ağ etkileşim akışını destekleyici bir güç olarak, ev ya da iş alanlarının da dahil olduğu mekânın kişiselleştirildiği, yani belirli zamanda mekân akışında yeni 'mekanların var olduğu' şeklinde anlam kazanmaktadır. Bunlar iletişim ağlarında yaratılan ve insanların amaçları doğrultusunda tekrar ortaya çıkan yakınsama noktalarıdır (2007, 172). Aynı şekilde zaman da kişiselleştirilmekte ağ etkileşimi yoluyla sıkışmakta ve ardışıklığını yitirebilmektedir. Dolayısıyla 'belirsiz zaman' kavramı ortaya çıkmaktadır. Zaman ve mekânın kişiselleştirilmesi aslında mobil aracılı mikro koordinasyon ile başlamamıştır. Gerçekten bu yeni zaman-mekân formları son on yılda ağ toplumuna geçişin tamamlayıcı bir parçasıdır (Castells, 2000). 
İnternet ve diğer teknolojiler, sosyal yaşamda zaman ve mekânın anlam değiştirmesinde önemli rol oynamaktadır. Bireylerin mobil iletişim yoluyla teknolojinin sağladığı esnekliği kullanmaları, mikro-koordinasyonu ya da yer ve zamanın kişiselleştirilmesini yeni seviyelere taşımaktadır. Bu durum, yer ve zamanın her kullanıcı tarafından aynı ölçüde ya da aynı şekilde kişiselleştirildiği anlamına gelmemektedir. Ancak her zaman her yerde kullanılmakta olan ağ teknolojileri yoluyla şekillenmekte çeşitlenmektedir. Nitekim, 'mobil iletişim teknolojisinin yaygınlaşması, mekân akıșı ve belirsiz zamanın günlük yaşamımızın yapıları olarak yayılmasına büyük ölçüde katkıda bulunmaktadır' (Castells vd., 2007, 171). Hiper koordinasyon özgün bir pratik olarak kişiselleşmeyi artıran etkileşim yolu olarak ortaya çıkmakta ve yaygınlaşmaktadır. Hiper koordinasyon, cep telefonunun tesirli kullanımı anlamına gelmekte ve sürekli etkileşimler ya da kısa mesajlar formunda da olabilmektedir.

Licoppe (2003), telefon üzerinden sürdürülen etkileşimleri; küçük konuşma ve boş sohbet arasındaki seviyeleri ve daha kişisel konuların derinlemesine tartışılmasına kadar değişebilen dizileri 'görüşme modu' (conversational mode) olarak belirtmektedir. Öte yandan, Castells ve diğerleri tarafından 'seni seviyorum' demek gibi sık kullanılan kısa sesli ya da yazılı mesajlar 'bağlantı modu' (connected mode) olarak ifade edilmektedir (Castells vd., 2007). Görüşme modu hem sabit hatlarla oluşturulan iletişim, hem de mobil iletişim için tipiktir; bağlantı modu ise mobil iletişimde bir fenomendir (Lai, 2007; Licoppe 2003). Çoğu zaman bu tür mesajlar bu kapsamda anlamsız görünmekte, ancak Johnsen'in açıkladığı şekilde, "İletişim, enstrümantal bilgi alışverişi dıșında çok önemli bir işleve sahiptir", bir sosyal duygu fikrini desteklemek dışında, içerik ve işlev olmadan bir bilgi taşıyıcısı olmaktadır $(2003,163)$. Bu kapsamda 'dijital hediyeler' ergenlik çağında özellikle yaygın durumdadır ve geleneksel gençliğin geçici pratikleriyle karşılaştırılabilir (Johnsen, 2003; Ling and Yttri, 2002). İster görüşme ya da ister bağlantı modunda olsun, mobil telefon yoluyla hiper koordinasyon bir tutkal gibi yapışkan özelliğinde 'tesirli-sembolik öz' ile yüklüdür (Licoppe, 2003, 164).

Mikro koordinasyon gibi hiper koordinasyon da iletişim ortamının bireyselleşmesine doğru eğilimin bir yansıması ve uzantısıdır. Tanım olarak, hiper koordinasyonu, mikro koordinasyondan ayıran şey, iletişim içeriğinin kendine özel doğasıdır (Campbell, 2008; Ling ve Yttri, 1999, 2002; Ling, 2004). İletişim kapsamının ötesinde hiper koordinasyonun beslediği sosyal ilişkiler daha çok bireysel hale gelmektedir. Mobil iletişimin; sosyal ağ dügümlerinin kişisel ilişkileri güçlendirdiği açıktır (Campbell and Russo, 2003; Campbell and Kelley, 2006; Ling, 2004; Park, 2005). Bu aynı zamanda ortak coğrafyaya sahip geleneksel topluluklara karşıt olarak, giderek daha seçici olan sosyal ağların kişiselleştirilmesini sağlamaktadır. Sonuç olarak, mekân-temelli bağlantıya karşıt olarak, yeni iletişim teknolojileri yoluyla birey bireye bağlantıya yönelik bir eğilim görülmektedir (Wellman, 2001). Wellman'a göre, yeni iletişim teknolojilerinin sürekli büyümesiyle birey (yer, ev ya da çalışma grubu değil) otonom bir iletişim düğümü (node) haline gelmektedir $(2001,238)$. Bu nedenle gerçek anlamda sosyal ağlar, giderek "kiş̧isel ortaklık ağları" (Otani, 1999; Wellman ve Potter, 1999) ve "kişisel iletişim ağları" (Campbell ve Russo, 2003) şeklinde ifade edilmekte, daha kişisel hale gelmektedir. Miyata ve arkadaşlarının ifadesiyle mekân-temelli hane-içi ilişkilerden kişiselleștirilmiş (kişiden kişiye) etkileșimler ve özelleşmiş 
(rolden-role) etkileşimlere geçiş, internet ve özellikle kablosuz kişisel iletişimle kolaylaştırılmaktadır (Miyata vd., 2005, 430).

Akıllı telefon modası bireysel iletişime doğru bir ilerleme ve kamusal alanların kişisel amaçlar için kullanılmasının yolunu açmaktadır. $\mathrm{Bu}$ aygıtlar artık kamuya açık alanda kullanıcıya çok sayıda yapay dokuya sahip sosyal bağlantı sağlamaktadır; istenmeyen melodiler, sesler, tweetler, kısa/yarım konuşmalar vb. gibi. Kamuya açık ortamlarda sosyal norm davranışlar sıklıkla bu tür telefon görüşmeleriyle çelişmektedir (Love and Kewley, 2005). Böylece mobil telefonunun kullanımı, fırsatlar kadar zorluklarla karşı karşıya kalmakta ve sonuçta sosyal bilim araştırmalarının aktif bir alanı haline gelmektedir.

Mobil telefon kullanımı birçok araştırmada incelenmiştir (Campbell ve Russo, 2003; Rice and Katz, 2003; Murtagh, 2001). Mobil telefona özel davranışların topluma açık sınırları ya da kabul edilebilir görgü kuralları gibi neyin uygun olduğu konusunda kamuoyunda bir görüş birliği mevcut değildir (Wei ve Leung, 1999, 13) ve kişiye özel ve kamuoyu arasındaki sınırlar sürekli müzakere edilmektedir.

Mobil telefonun kamuya açık bir şekilde kullanılması sonucunda, başka bireyler bilinçsizce izleyici rolüne sokulmaktadır. İletişim, hattın ötesinde diğer kişiyle yapılsa da bu iletişime kulak kabartan, bunları gözetleyen bir karşı izleyici durumu söz konusudur (Fortunati, 2003, 11). Fortunati, bu fenomeni 'birkaç bilgi öğesinden yola çıkarakyeniden anlam inşa edebilmekten ibaret olan dilsel bir hazine $a v i^{\prime}$ olarak tanımlamakta ve bir nevi oyun olarak nitelendirmektedir. Paragas (2005), diğer insanların cep telefonu görüşmelerini izleyen ya da gözetleyen insanlara ait bir tutum bulmuştur; özel konuları gözetlemek bir eğlenme biçimi olarak görülmektedir.

Teknolojinin kullanımı konusunda bazı araştırma bulgularında, örneğin kullanımlar ve doyumlar temelinde cep telefonu kullanımının başlıca nedenlerinin moda ve statü olduğu, çünkü telefonun sosyal kimliğin sembolik ifadesini sağladığı ortaya çıkmaktadır (Leung ve Wei, 2000). Erwing Goffman'a göre (1959) cep telefonu, kişilerin kendi sembolik özelliklerini gösterme aşamasında (sahne) performanslarını yönetme stratejisinin bir parçasıdır. Katz ve Aakhus (2002) cep telefonlarının ve diğer kişisel iletişim teknolojilerinin benimsenmesi ve kullanılmasıyla ortaya çıkan sosyal değişimlerdeki tutarlılıkları açıklamak için 'Apparatgeist' kavramını ortaya koymuştur. Bu kavrama göre mobil aygıtlar birey ya da grubun bir uzantısı haline gelmekte ve davranışsal normlarının bir sembolü olmaktadır.

\section{Araştırmanın Amacı}

$\mathrm{Bu}$ çalışmada amaç, mobil iletişimin entegrasyonuyla insanların sosyal hayatında yarattığı değişimleri sorgulamak, bu değişimleri koordinasyon, güvenlik ve etkileșim bağlamında farklı yaş gruplarında değerlendirmektir. İnsanların cep telefonu gibi kişisel iletişim teknolojilerini nasıl kullandığı, ne düşündüğü konusundaki tutarlılık ve yenilikleri belirlemek, amaçlanan ve amaç dışına çıkan sonuçlarının neler olduğunu belirlemektir; telefon edinmeye sosyal bakış, yaşama etkisi, koordinasyon biçimleri, örgütlenme değişimleri, davranış değişimleri, kişisel teknoloji kullanımıyla ilgili yaşanan sıkıntılar vb. gibi. Araştırmanın amaç soruları şöyledir:

- $\mathrm{X}, \mathrm{Y}$ ve Z kuşaklarının akıllı telefon edinmeye sosyal bakışı nasıldır?

- X, Y ve Z kuşaklarında akıllı telefonun yaşama etkisi nasıldır? 
- X, Y ve Z kuşaklarının akıllı telefonla ilgili nasıl bir davranış kazanımı mevcuttur?

- Birinci, ikinci, üçüncü seviye ilişkilerde güvenlik, sosyal etkileșim ve güvenlik eğilim ne yöndedir?

\section{Yöntem}

$\mathrm{Bu}$ araştırma yorumlayıcı bir yaklaşımla sosyal bir olguyu katılımcıların bakış açısından sahip oldukları düşünce duygu ve tutumları anlama ve yorumlama çabasındadır. Bu çabada araştırmanın sorularını yanıtlamada Holstein ve Gubrium'un (2004) aktif görüşmeleri kapsayan nitel metotların, diğerlerinin ne hissettiğini ve ne düşündüklerini anlamanın iyi bir yolu olduğu fikri rehber alınmaktadır. Buradan hareketle karmaşık anlamlarla ilgili algılamaların belirlenebilmesinde bu araştırma kapsamında nitel araştırmalardan, yarı yapılandırılmış derinlemesine görüşme tekniğinden faydalanılmıştır. Görüşmenin önceden hazırlanmış görüşme protokolüne bağlı olarak sürdürülmesi ve daha sistematik ve karşılaştırılabilir bilgi edinme amaçlanmıştır (Yıldırım ve Şimşek, 1999, 283). Açıklayıcı çalışmalarda yüz yüze görüşmeler, az bilinen olguları ve karmaşık süreçleri açığa çıkarmada katılımcıların algılarına rasyonel bir çerçeve sağlayabilir. Görüşmeler yüz yüze yapılmakta ve görüşmeler sırasında ses kaydı alınmaktadır. Bu araştırma sürecinde kavramlar, temalar ve bunların ilişkilerine yönelik açıklamalara yönelik yardımcı verilere ulaşılmaya çalışılmaktadır. Araştırma boyunca, katılımcıların belirttikleri, tekrar eden durum ve olaylar, kendi durumlarında buldukları sorunlar ve örnekleri dikkate alınmaktadır.

\section{Örneklem}

Bu araştırmada toplamda 11 katılımcıyla görüşme yapılmıştır. Amaçlı olarak seçilen örneklem üç farklı yaş grubundan oluşmaktadır. Sınırlı sayıda kişi ile bütünsel ve derinlemesine çalışılarak elde edilen sonuçlar yine benzer özellikleri gösteren kişileri anlamada kullanılmaktadır (Patton, 1990, 184) Örneklemde yer alan üç grup şöyledir:

- Ergen grup (Z); 2000 yılı sonrası doğumlu, 3 katılımcı (öğrenci), Z1ve Z2 erkek 16 yaşında, Z3-kadın 15 yaşındadır.

- Genç grup (Y); 1980 sonrası doğumlu, 5 katılımcı (öğrenci ve mezun öğrenci), Y1-21yaş, Y2-23 yaş, Y3-25, Y4-25 yaşında kadın ve Y5-27 yaşında erkektir,

- Yetişkin grup (X);1960-1970 sonrası doğumlu 3 yetişkin ebeveynle görüşmeler yapılmıştır. X1-47 yaş-kadın öğretim üyesi, X2-55 yaş-erkek yönetici, X3-46 yaşında kadın öğretim üyesidir. Bu gruptaki katılımcıların her biri 16-25 yaş aralığında iki çocuk sahibidir.

Her gruptaki katılımcıların akıllı telefon sahibidir. Görüşmelerin başlangıcında akıllı telefon sahipliği ve kullanımına sosyal bakış tartışılmaktadır. Etkileşimde araç tesirinden duygu ve hislerin alışverişine doğru bir hareket hedeflenmekte, koordinasyon ve güvenli iletişim değerlendirilmektedir. Değerlendirmede Calhoun'un sosyal etkileşimi temel alınmaktadır (1987, 1992; Ling and Yttri, 2002). Calhoun birinci seviye kişisel ilişkileri direkt bireyler arası ilişki (tanıdık aile ve yakınlarla iletişim), ikinci seviye ilişkileri doğrudan ancak karmaşık bir iletişim sisteminin arabuluculuk ettiği ilişkiler (tanıdık ve yakınlarla bir internet uygulaması kullanarak iletişim) ve üçüncü seviye ilişkiyi bir iletişim sistemi yoluyla ama hiç yüz yüze gelinmeden (gerçek hayatta hiç yüz yüze gelinmemiş kişi ya da 
kişilere bürokrasi gibi resmi bir pozisyonda bir başvurunun gönderilmesi vb.) olan ilişkiler olarak belirlemektedir. Bu araştırmada akıllı telefon yoluyla ilişkinin nasıl farklılaştığı sorgulanmaktadır.

\section{Araştırmanın Sınırlılıkları}

Araștırmanın başlıca sınırlılıkları tekrar edebilirlik, güvenirlik ve nesnelliktir. Bu sınırlılıklar aynı zamanda nitel araştırmaların "yorumsayıcı" doğasının bir sorunudur (Kümbetoğlu, 2005). Dolayısıyla nitel araştırmalar için güvenirlik, geçerlik ve nesnellik araştırmanın "tutarlılı̆̆ı" ile ilgilidir ve araştırmacının tüm araştırma boyunca nesnelliği sağlamasına da sıkı sıkıya bağlıdır. Diğer taraftan katılımcıların tümü Eskișehir'de yaşamaktadır. Bu hususta araștırmanın farklı coğrafyalarda tekrar etmesi daha genellenebilir bulgulara ulaşılmasına katkı sağlayabilir. Ayrıca, evrenin oldukça geniş olduğu düşünüldügünde örneklemin küçüklüğü bir başka sınırlılıktır. Seçilen örneklemin evreni temsil etme yetisinin bulunmaması ve derinlemesine görüşme ile elde edilen verilerin istatistiksel geçerliliğinin olmaması, sonuçların yorumlama ile genel değerlendirme karakteri taşımasına neden olmaktadır.

\section{Araştırma Bulgularının Değerlendirilmesi}

Daha sistematik bir tartışmaya olanak sağlaması bakımından bulgular dört bölümde, gruplar hâlinde açıklanmaktadır. İlk olarak katılımcıların akıllı telefon edinmeye bakış açısı, ikinci bölümde akıllı telefon kullanım biçimleri ve yaşama etkisi, üçüncü bölümde akıllı telefonla birlikte gelen davranış kazanımları, beşinci bölümde ilişkilerinde güvenlik, sosyal etkileşim ve güvenlik sıralaması ve mobil telefonun tesirli durumları açıklanmaktadır.

\section{Akıllı Telefon Edinmeye Sosyal Bakış}

Katılımcılara ilk olarak katılımcıların telefon edinmeye ergenlerin sosyal bakışının nasıl olduğuna yönelik sorular yöneltilmiştir. Z kuşağı katılımcıları için telefon edinimi olmazsa olmaz bir gereksinimdir. Miyata ve arkadaşlarının ifade ettiği gibi mekân-temelli ilişkilerden bireyselleşmeye doğru ve özelleşmiş etkileşimlere (rolden-role) geçiş bunu kolaylaştıran mobil cihazları (Miyata ve ark. 2005, 430) cazip kılmaktadır. Sosyalleşmek, çevre edinmek ve topluma ayak uydurmak için akıllı telefonun şart olduğu, statü göstergesi olmadığı belirtilmekte ve akıllı telefon çok önemli ve vazgeçilmezdir. Bu grup teknoloji kullanabilmeyi 'aşamaları olan bir yetenek' olarak görmekte; bu yeteneklerinin 'takdir' edilmesini beklemektedirler:

"Gençler için akıllı telefon olmazsa olmaz. Sosyalleşmek istiyoruz. Ben güzelim yakışıklıyım görsünler istiyoruz.", "Ben sosyalim. Orada var olmak önemli. Telefonu olmayan asosyal olarak görülüyor; onunla konuşmuyorlar. Sosyal medyada değilsen seni kimse tanımaz" "Hayatı kolaylaştırıyor, ikincisi farklı olduğunu hissettiriyor. Mesela piyano çalıyorum. Hocam sınıfta enstrüman çalan var mı diye sorduğunda, ben parmak kaldırmam arkadaşlarımın beni göstermesini beklerim (takdir edilmek). Bizler teknolojiyi kullanmayı yetenek olarak görüyoruz, enstrüman çalmak gibi, hobi gibi. Herkes yapamaz. Şarkı söyleyen bir sürü insan var ama bunun bir de üst düzeyi var. Uzman yani” (Z1). "Benim yaşımda akıllı telefon olmayınca yadırganır. Teknolojiye yakınlık olarak görülür, artık olmayanı sorguluyorlar neden almıyorsun gibisinden" (Z2). "Cep telefonumu olmayınca arkadaşlarımdan bir farklılık hissediyordum. Sahip olanlara özenirdim. Olmayınca arkadaş toplumundan dışlanıyorsun. Cep telefonuyla hava atma durumu, şekilcilik var. İyi markalı olan çıkarıp masaya koyar. Küçükler telefonu ilk aldıklarında çok gösteriş yapıyorlar, telefonlarını ortada tutuyorlar ama onlar uzun süre kullananlar öyle yapmıyor, çünkü hevesini almış oluyor. Sonradan şekilcilik kalmıyor" (Z3). 
Y kuşağını temsil eden katılımcılar telefon edinmenin ekonomik seviyenin bir göstergesi olmadığını ve telefonun belli birkaç özelliğinin dikkate alındığını ve bunların dışındaki teknolojik özelliklerinin bilincinde olunmadan telefon edinildiği kanısındadırlar. Telefon edinmede özenti, gösteriş ve şekilciliğin rol oynadığını, çevrenin etkili olduğu ancak çağın mutlak bir gereksinimi olduğu konusunda hemfikirdirler. Katılımcılar ifadeleriyle Skog'un görüşünü desteklemektedirler (2002): “Gençler özellikle cep telefonunu sembolik bir ifade biçimi olarak kullanmakta, sosyal statüyü ve grup üyeliğini temsil etmek için bir cep telefonunun fiziksel görünümüne güvenirler":

"Gösteriș, șekilcilik ön planda. İnsanlar cebinde beș kuruș olmasa da en iyi telefona sahibi olmak istiyor, yemeyip içmeyip bu telefon ediniyorlar. Telefonu sadece fotoğraf çekme özelliğine göre alıyorlar. Genel olarak, 'Acaba senin telefonun kamerası nasıl? Kaç piksel?' bununla ilgileniyorlar. Elindeki son teknolojinin hiçbir özelliğini bilmez, onun için sadece fotoğraf kalitesi önemlidir" (Y1).

"Herkeste olmak zorundaymış gibi hissediliyor, özenti var. Dedem 90 yaşında akıllı telefon aldı, üstelik kameralı. Oyun oynuyor kullanıyor. Telefon edinmede çevre etkili oluyor. İnsanlar şöyle fotoğraf çekme özellikleriyle reklam yapıyorlar, birbiriyle yarışıyorlar sen yedi aldıysan ben sekiz alırım gibi" (Y2). "Büyüklerim gerekli olmadığını söylese de herkes için gerekli bir şey, benim yaş grubum için olmazsa olmaz. Yaşıtlarımız arasında olmaması bir dezavantajdır. Oyalanma, sosyal medyada takılma, anlık iletişimleri yapmak, gruplarla iletişim halinde olabilmemiz için okuldayken bile iletişim halinde olabilmemiz için şart. Bir bilgisayarda yapabileceğiniz her şeyi telefonda yapabiliyorsunuz Paramız olmasa da edinmek zorundayız" (Y3). "Markalar statü göstergesi sayılabilir. Telefon markası iyiyse telefonunu çıarır, ortaya koyar insanlar; gösteriş. Ben öyle bakmıyorum, bilgi bulmak araştırmak, depolamak, benim işime yaraması önemli. İhtiyaç. Girmek zorunda hayatımıza. Her şeyin cankurtaranı" (Y4).

X kuşağını temsil eden katılımcılar için telefon edinmenin statü göstergesi olup olması önemli değildir. Bu kuşak temsilcileri işine yarayan ve amacına uygun telefon ediniminden yanadır. Telefon ediniminin statü değil, eğitim düzeyleriyle ilişkili olduğunu belirtmektedirler:

“Gençler bir statü göstergesi kabul ediyor ama benim için statü önemli değil; acil eşime, çocuklarıma, anneme ulaşabilmek için önemli" (X1).

"Marka önemlidir, çünkü rahat kullanacağım telefonu tercih ederim, hafıza olarak beni sınırlamasını istemem. Bazıları için özentidir. Sırf bu iş için çalışanlar var. Birkaç ay çalışıp aldıkları maaşla telefonu edinip işten ayrılanlar var. Ben işime ve amacına uygun bir telefonun peşindeyim. Biraz şekilcilik var. Bazı insanlarda ilk çıkan benim olur mantığı ile hareket ediyorlar" (X2).

“Telefon bir prestij olarak algılanıyor. Gösteriş diyemem gençlere bakınca onlarınki mecburiyet. Özelliklerine dikkat ediyorlar. Kendi içlerinde sinıflamaları var. Gösteriş için kullananı var, bilinçli kullananı var. Bu durumun eğitimle ilişkili olduğunu düşünüyorum. Evinde yemeyip içmeyip telefon için yaşayanlar var ne yazık ki (X3).

\section{Akıllı Telefon Kullanım Biçimleri}

$\mathrm{Bu}$ aşamada X, Y ve Z temsilcisi katılımcıların sosyal yaşamlarında akıllı telefon kullanım pratikleri ve yaşama dair getirileri sorgulanmaktadır. Z kuşağı temsilcisi katılımcıların sosyal ağlar üzerinden sosyalleşme ve iletişim boyutları diğer kuşaklardan farklılaşmaktadır. Bu grupta, birbirlerine fark atma, uzmanlaşma, rekabet ve ödüllendirilme istekleri ön plana çlkmaktadır. 'Farklı olmak' isteği baskındır. Dijital rekabet (takipçi kazanmak, beğenilmek) ve bunun sonucunda 
ödüllendirilmek (dijital hediyeler), bu ödüllendirilmeyi sergilemek (hikayelerde paylaşmak) önemli görülmektedir. Bu durum Johnsen'in (2003) iletişim araçlarının enstrümantal bilgi alışverişi dışında, içerik ve işlev olmadan bir bilgi taşıyıcısı olması ve ergenlik çağında dijital hediyelerin özellikle yaygın olduğu fikrini destekler niteliktedir (Johnsen 2003; Ling and Yttri 2002). Ayrıca samimiyet artışı (kankalık) ve bu durumu sergilemek ve "çok seviliyor olma" farklılığını ortaya koyma açısından önemli görülmektedir:

\begin{abstract}
"Fotoğraf çekip üç gün üst üste karşıllklı göndererek ikon, bu ikonları artırarak gün kazanıyorum ve bu serileri artırıyorum. Eğer 24 saat içinde bir 'snap' atılmazsa seri gidiyor. Arkadaşınızın ismine ikon geliyor, kankanızın değiştirebilinen bir ikonu oluyor. Kaç gün yaptığınızın sayıları önemli. Biriyle tanışıyorsun ve haydi gün yapalım diyorsun. Benim 256 oldu, 600 gündür birbirine günaydın, iyi geceler diyen arkadaşlarım var mesela. Bu durum gençlerin birbiriyle tanışma şekli oldu (kankalık durumu). $\mathrm{Bu}$ arkadaşınla daha samimi olduğunu gösteren bir şey, kankalık. Mesela bir arkadaşımla çok mesajlaşıyoruz, o zaman siz birbirinizin 1 numarasısınız diye ikon geliyor, onurlandırıyor, ödüllendiriyor. Başka bir ikon mesela kalp geliyor; 1 aydır kankasınız, iki aydır kankasınız filan." Her 100 oluşunda ve 100'ün katlarında ikinizin birlikte göründüğü bir fotoğrafa 100 işareti konularak hikâye kısmına konuluyor; herkes görsün diye. Biraz görgüsüzlük. Ama rekabet var. 0 nedenle yüksek rakamlara ulaşmaya çalışıyorsun. Yorucu". "Herkes farklı olmayı sever" Topluma ayak uydurmak ve bağlantıda kalmak; Bunu herkes yapıyor. Sürüden ayrılmayacaksın yakında benim 365 olacak, yıldız alacağım". (Z1).
\end{abstract}

Takipçi kazanmak da 'çok seviliyor' ve 'mutlu' olmanın bir göstergesidir. Gerçek hesap açmak, ciddi ve kişiye özel durumları, kişiye özel ciddi fotoğrafları paylaşmak için yapılmaktadır. Gerçek hesaplara ilave olarak, yakın çevrelerinin sorgulamalarından kaçmak ve özellikle özgür olma işlevi yüklenmiş gizli hesap açmak (akranlarla komik video-görüntü paylaşmak, gülmek, eğlenmek için) bir gereksinimdir. Gizli takip, gizli hesap ve takipçi sayısı artırma rekabeti diğer ön plana çıkan kullanım özelliğidir; takipçi sayısı artırmak, diğerlerine fark atmak, üstünlük; sevilme ifadesi olarak algılanma eğilimindedir. Gizli hesaplar, tanıdıkları yakın çevrenin sorgulamalarından kaçınmak için ve daha özgür olma işlevi yüklenmiş bir sosyalleşme olanağ sağlamaktadır. Bunun dışında, gençlerin tanışma ve arkadaşlık biçimleri farklı bir boyut kazanmaktadır. Sosyal ağlarda arkadaşlık kurmak, yorucu olarak nitelendirilse de akranlara ayak uydurmak için zorunluluk yaratmaktadır:

\footnotetext{
"Sosyal medya kullanan 1 milyar kişi var. Onlardan biri girip benim profilime bakabilir. Bu nedenle herkes profilini gizliyor. Profil gizli ama 'üç yıl önce aynı okuldaydık tanıyordum' deyip hemen takibe atıyorlar. Bu aslında 'yanlış anlama, takibe atıyorum ama sadece tanıştığımız için' demektir. Üç gün önce metroda tanıdığı çocuğu bile takibe atabiliyor insanlar. Burada amaç her eklediğim kişiyle iletişim kurmak değil. Kız ve erkek ilişkisinden ziyade takipçi sayısı rekabeti. Kimin daha çok takipçisi varsa bak ne çok seviliyorum demek gibi bir anlayış. Çok saçma ama böyle bir algı var" (Z1). "En çok okul işlerinde ve fotoğraf göndermek için kullanırım. Genelde aile grubu, arkadaşlarım ve okul gruplarım var. Twitter Instagram Snapchat kullanırım. Hobilerim var, bilimle ve oyunlarla ilgili hesapları takip ediyorum. 6 oyunum var arada bir oynarım. En çok sonradan hatırlamak için kayıt altına almak için belge görüntüleme kullanırım. Bizim kuşakta Facebook artık kullanılmıyor. Instagramda ikinci hesap açanlar var farklı isimlerde. Onlar kendi hesaplarında daha ciddi ve özel fotoları paylaşıyor, diğer hesaplarında da saçma sapan şeyler paylaşıyorlar. Komik sayılacak şeyler; daha serbest. Asıl hesap daha resmi; bu hesabı yakınları ebeveynleri takip ediyor. Bu diğer hesapları sadece arkadaşlarına açıyor. Biraz gizlenmiş oluyor (Z2).
} 
Z kuşağı temsilcileri, Facebook dışında en çok Whatsapp, Instagram, Twitter gibi sosyal ağ platformlarını daha çok kullanmaktadırlar. Ayrıca teknolojinin getirdiği yeniliklerin ulaşabildikleri, kendilerine yarar sağlayabilecekleri ne kadar uygulama ve uygulama özelliği varsa sonuna kadar zorlamaktadırlar. Başka bir deyişle kendine yarayanı araștırarak, bularak, en son sınırına kadar öğrenme hevesinde ve neyi, nasıl ve ne amaçla kullanabileceklerinin peşindedirler.

Y kuşağı temsilcisi katılımcıların kullanım pratikleri hayatlarına kattığı yenilikler sorulduğunda her biri söze bağımlılık konusuyla başlamaktadır ve bununla baş etmenin yollarını arama savaşında olduklarını belirtmektedirler:

"İpin ucunu kaçırma noktasına geldim ve artık kendime set çekebiliyorum" (Y1).

"Ders çalışmamı engelliyordu, artık çalışma odamın dışında bırakıyorum" (Y2). "Beni kilitliyor" (Y3).

Y kuşağı temsilcilerinde mobil telefonlar eş zamanlı ve ileri zamanlı koordinasyon için aktif olarak kullanılmaktadır. Hayatlarının vazgeçilmez bir unsurudur. Kullanımın keyiflendirici ve eğlendirici olduğu vurgulanmaktadır. Bilgisayar taşımak yerine artık akıllı telefon tercih edilmekte, kariyer bilgilerini ve belgelerini depolama, bu tür bilgileri takip etme, araștırma, müzik dinleme, haber edinme ve gündemi takip etme, sosyal medyada var olmak, fotoğraf ve bilgi paylaşımı ve bu paylaşımları takip etmek, alışveriş, bankacılık, eğitimle ilgili uygulamalar, spesifik sorunları çözmek için akıllı telefonlar kullanılmaktadır:

"Koordinasyon yapıyorum, sosyal ağları kullanırım. Hayat kurtarıcı. Tam bir can simidi" (Y1). "Artık bilgisayar kullanmıyorum her şeyim cep telefonunda, çünkü elimin altında. Hayatımın bir parçası o" (Y2). "Hayatımıza gömüldü. Spesifik sorun çözer en küçük şeyimi bile Google'a yazarım, araştırırım” (Y4). Anlık hikayeler filan, paylaşmak kolay. Paylaşma isteğimi çok artırdı" (Y5).

Bu kuşaktaki katılımcıların Instagram uygulamasını aktif kullanımına bağlı olarak fotoğrafçılığa ilgi artışı görülmektedir:

“Çoğu fotoğrafçılık uygulaması, fotoğraf paylaşmayı seviyorum. Fotoğrafçılık alanına ayrıca bir ilgim oluştu, profesyonellik anlamında" (Y1). Fotoğraf çekerim telefonuma bir şey olursa bana da olur" "Bütün bilgilerimi burada saklıyorum" (Y2). "Daha çok fotoğraf çeker oldum" (Y5).

X kuşağı temsilcisi katılımcıların akıllı telefon kullanım pratikleri, hayatlarına kattığı yenilikler sorulduğunda; sağlık uygulamalarını kullanmaya başlamak, fotoğraf uygulamaları (fotoğrafa merak sardıkları için), GPS, müzik, sesli kitap uygulamaları, mesleki anlamda gerekli uygulamalar, müzik dinlemek, radyo dinlemek; su içmek, ilaç içmek ve spor zamanlarını anımsatıcı uygulamalar (hatta zor durumda kalmamak adına bahane amacıyla alarm uygulamasını kullanmak); günlük planlama ve koordinasyonları sağlayan yardımcı programlar (yapılan ya da yapılacak işleri organize etmek); aile bireylerini korumacılık amaçlı takip için bireylerinde ortak olabildiği uygulamalar; okunması gereken şeyleri yükleyip sonradan okumaya izin veren uygulamalar; sosyal medya uygulamalarını (özel günleri kutlamak, kanaat önderliği yapmak aile bireyleri ile sohbet ortamı yaratmak, gerçek ortamda teknoloji bilgisiyle çocuklarını takdir etmek, aile bireylerini ve arkadaşları kim nerede ne yapıyor gözetlemek gibi amaçlarla) kullandıklarını belirtmektedirler. Bu kuşak temsilcilerinde iş odaklı kullanım ve koordinasyon daha yaygın görülmektedir. Cep telefonları günlük yaşam faaliyetlerini oturduğu yerden koordine edebilmek gibi 
hayatlarına yeni kullanım biçimleri katmaktadır (sağlık, finans, haber okuma, hava durumu, anlık iletişim ve haberleşme, kitap okuma, belge paylaşma, çoklu iletişim kurabilme, birbirini takip etme, hobi uygulamalarını takip etme, trafik uygulamaları, bankacılık uygulamaları, e-devlet vs.)

X kuşağı temsilcileri de ilginç olarak görüşme başlangıcında, sorulmadığı halde kendilerini akıllı telefonsuz yaşayıp yaşayamayacaklarını sorgulayarak başlamışlardır. Bu konuda denemeler yaptıklarını ve telefonsuz yaşayabildiklerini dile getirmektedirler. Sohbetin başında her biri bunu ifade etmelerine rağmen sohbet sonunda akıllı telefonun ne kadar hayatlarına gömülü olduğunu fark etmekte, hayrete düşmekte ve sohbet sonunda yanıldıklarını belirtmektedirler. Diğer kuşaklardan farklı olarak bu kuşakta özellikle aile bireylerinin birbirini takip edebilecekleri uygulamaları kullanmaları göze çarpmaktadır. Terör ve siyasi olayların olabilme olasılığından ileri gelen korkuların bu tür takip uygulamalarının kullanılmasına neden olduğu belirtilmektedir. Görüşme esnasında bu bir örnek olayla vurgulanmaktadır:

"Gençler özgür olmak istiyorlar, ancak terör ve siyasi olaylar bizi korkutuyor. Oğlum Almanca kursundayken yanındaki binada Rus büyükelçisi öldürüldü. Life360 uygulamasını kullanarak onu sakin sokaklardan taksiye ulaştırmayı başardık. Onu arka sokaklardan taksiye ulaştırıp yurduna gönderebildik. Böyle bir programı yüklemeseydik yolu kendi bulmak zorunda kalacaktı. Ama biz onu yönlendirdik. Eğer olmasaydı endişelenecektik (Bu uygulamada mesafe, hangi ulaşım aracı, kaç liraya gidersin görüyorsun)" (X1).

\section{Davranış Biçimleri (Mikro ve Hiper Koordinasyon)}

Z kuşağı temsilcileri diğer kuşaklara göre daha esnek koordinasyonlar yapma davranışı göstermektedirler. Rekabetçi, dijital ödül kazanmak için çaba harcama, gerçek hesabın yanı sıra sahte hesap açma, dijital eğlence biçimlerini keşfetme çabası, dijital ortam arkadaşlıklarını artırma çabası, okul hayatında dijital ortamlardan yararlanma (haber, bilgi, ödev alışveriși), dijital kayıt, sosyal medyada var olmak çabası, neyi, nasıl ve ne amaçla kullanabileceklerinin araştırılması gibi davranışlarına sahiptirler. Teknolojinin getirdiği yenilikler konusunda ulaşabildikleri, kendilerine yarar sağlayabilecekleri ne kadar uygulama ve uygulama özelliği varsa öğrenme çabası içerisinde ve bu çabayı sonuna kadar zorlamaktadırlar. Örneklemdeki katılımcılar diğer kuşaklardan farklı olarak 'satranç oyunu' gibi, dijital ortamda bir adım atmadan önce o adımı attıklarından sonraki birkaç adımı hesaplamaktadırlar.

Y kuşağı temsilcisi katılımcılar, Z kuşağıyla benzer olarak esnek koordinasyon yapma ve rekabetçi davranış sergilemektedir. Diğer kuşaklardan farklı olarak mobil iletişim cihazlarıyla 'zaman kaybını kontrol etme çabası' içerisindedir. Müzik, radyo dinleme, bilgisayar taşımak yerine telefon taşıma, fotoğrafçılıkla ya da diğer hobilerle ilgilenme, haber ve bilgi edinme, gündemi takip etme, kayıt altına alma davranışlarını akıllı telefon üzerinden gerçekleștirmektedir. Kariyer bilgilerini ve belgelerini her an ulaşabilecekleri akıllı telefonlarında bulundurmaktadırlar. Sosyal medyada var olduklarını ancak kontrollü paylaşımlarda bulunduklarını dile getirmektedirler. Saat taşıma davranışını terk etmektedirler ve spesifik sorunlarını telefon üzerinden dijital yolla çözme eğilimindedirler. Ayrıca kendilerini sosyal medyada sahte ve gerçek hesapların denetimini yapabilecek bilgi düzeyine sahip görmektedirler. Y kuşağı temsilcisi katılımcılar cep telefonunun kendi vücudunun bir uzantısı olarak (el, kol gibi) gördüğünü belirtmektedir (Hulme and Peters, 2002). 
X kuşağı temsilcisi katılımcılar, akıllı telefon sayesinde kendi sağlıkları ilgili konulara ve bu tür uygulamalara daha çok ilgi göstermeye başlamışlardır. Mesleki anlamda dijital olarak karşılayabilecekleri tüm gereksinimleri için akıllı telefonlarından yararlanmaktadırlar. Fotoğrafa merak sarmak, ancak fotoğraf makinesi taşımayı bırakmak belirttikleri yeni davranış biçimlerindendir. Müzik dinlemek için müzik listeleri oluşturmak, günlük yaşam faaliyetlerini oturduğu yerden koordine etmek (sağlık, finans, haber okuma, hava durumu, iletişim, kitap okuma, belge paylaşma, anlık haberleşme, çoklu iletişim kurabilme, birbirini takip etme, hobi gruplarını takip etme vb.), basılı kitaptan okumak yerine sesli kitap uygulamalarını kullanmak, planlama ve koordinasyon (özellikle işamaçlı koordinasyon yaygın olmaküzere, alarm ve anımsatıcıları kullanma; su içmek, spor saati, doktor randevuları, toplantı saatleri, günlük organizasyon için önceden uyarılmak ve hatta bunu alarm uygulamasını zor durumda kalmamak adına bahane amacıyla kullanmak, beden diliyle yanlış işaretler vermenin önüne geçmek ve böyle durumları baştan engellemek), aileyi bireyleriyle sürekli etkileşimde bulunmak ve denetim altında tutmak, gruplar arası etkileşim ve koordinasyonlar (veli grupları, aile grupları, okul arkadaşları, proje grupları, hobi grupları, samimi arkadaş grupları vs.), konum belirleyicileri kullanma (GPS, haritalar vs.), alışverişleri dijital olarak yapmak, kutlamaları dijital yoldan yapmak edindikleri diğer yeni davranışlar biçimleridir.

\section{Güvenlik, Sosyal Etkileşim ve Koordinasyon}

Katılımcılara birincil seviyedeki ilişkileri açısından (aile bireyleri ve gerçek hayatta tanıdıkları kişilerle doğrudan kişisel ilişkiler) güvenlik, sosyal etkileşim ve koordinasyon sıralamasında öncelik hangisindedir diye sorulduğunda ilk sırada sosyal etkileşim gelmektedir. Dolayısıyla üç kuşakta birincil seviyede ilişkilerde bilgi ve kültür vb. gibi karşılıklı aktarımlar ilk sırayı almaktadır. Íkinci sırada koordinasyon yani bilgi ve becerilerin birleştirilmesi ve bu amaçla faaliyet gerçekleştirme gelmektedir. Güvenlik üçüncü sırada gelmektedir.

İkincil seviye ilişkilerde (gerçek hayatta yüz yüze gelinmiş kişilerle doğrudan ancak karmaşık bir iletişim sistemiyle kurulan ilişkilerde-mobil iletişim sistemleri gibi) güvenlik, sosyal etkileșim ve koordinasyon sıralamasına en önemli unsurun hangisi olduğu sorulduğunda X kuşağından iki kişinin haricinde, doğrudan ilişki kurmada yanıtlar aynıdır; yani önce sosyal etkileşim, ardından koordinasyon ve en son güvenlik gelmektedir. Genç kuşaklardan farklı olarak X kuşağı temsilcilerinden X1 ve X3 ilk sırada koordinasyona, sonra sosyal etkileşime öncelik vermektedir.

Üçüncül seviye ilişkilerde (hiç yüz yüze gelinmemiş ve sadece bir iletişim sistemi sayesinde ilişki kurmak) güvenlik, sosyal etkileşim ve koordinasyon sıralaması ise şöyledir: Bütün katılımcılar için ilk sırada güvenlik, ikinci sırada koordinasyon ve sonrasında sosyal etkileşim gelmektedir. Sadece X2 için sosyal etkileşim ikinci sırada, koordinasyon üçüncü sırada gelmektedir. Z ve Y kuşakları temsilcileri birincil seviye ilişkilerde uyumluluk göstermekte X kuşağında öncelik farklılıkları belirmektedir.

\section{Kuşaklararası Karşılaştırmalar}

Kuşaklararası ilişkilerde, ergen ve genç kuşak (Z ve Y) yetişkin kuşağın (X'in) öğreticisi rolünü üstlenmektedir. Ayrıca yetişkinlerin teknolojiye daha zor adaptasyon sağladığ

“Spesifik sorun çözer en küçük şeyimi bile Google’a yazarım, araştırırım. Anneme de bunu aşılıyorum. Ona telefon yeni aldık, ne gelirse aklına yaz diyorum. 0 biraz uyum 
problemi yaşıyor çünkü ona sonradan gelen bir alışkanlık. 45 yaşında. Ben daha kolay adapte oluyorum o zor adapte oluyor (Y4). Oğlum çok yardımcı oluyor bazı şeyleri ona soruyorum (X3).

Yetişkin kuşak katılımcıları, gençlerin mobil telefonu daha bilinçli kullandığını ifade ederek bu durumu desteklemektedir:

“Oğlum benden daha bilinçli kullanıyor. İşine yarayanın peşine düşüp elde ediyor. Gitar çalmayı internetten öğrendi. Yazılım programlarını internetten geliştiriyor. Kendine katkı anlamında o çok daha verimli kullanıyor, birkaç adım ötesini hesaplıyor. Ben onun kadar verimli kullanmıyorum sanırım" (X3). "Oğlumun İngilizce telaffuzu bunun sayesinde çok gelişti” (X2), "Oğlum gitar çalmayı ondan öğrendi” (X3).

X kuşağı temsilcisi katılımcılarından biri araca bağlı baskı konusunda genç kuşakların sürekli gözetim altında olduğunu ve genç kuşağın önceki kuşaklara göre her şeyi daha hızlı tükettiğini, yaptıklarıyla sorgulanmamak için akranlarının çoğunlukta olduğu farklı sosyal ağlar kullandıklarını vurgulamaktadır:

\begin{abstract}
"Ben çocukken sokağa çıkıp kaybolabiliyordum. Ama onlar her ortamda kontrol altındalar. Benim kadar özgür değiller", "Snapchat uygulamasını indirmiştim, oğlum 'anne, sen de mi buradasın' dedi. Anladım ki bu ortam gençlere özel ve özgür olmak istiyor. Ben de kaldırdım" "Snapchat'te her şey çabuk tüketiliyor o nedenle gençlerin daha çok orada olduklarını düşünüyorum. Sorumluluk alacağı bir şey yok ve o anı yaşamış bitirmiş oluyorlar. Bir daha da orada yaptıklarıyla sorgulanmak istemiyorlar" (X3). "Tam verimli kullanmıyorlar. Sadece belli uygulamaları kullanıyorlar. $\mathrm{Bu}$ uygulamaların onlarda baskı yaptığını düşünüyorum” (X2).
\end{abstract}

Bireyselleşme konusunda Y kuşağı temsilcisi katılımcılar bireyselleşmeyi bazen kendilerinin istediğini belirtmektedir. Görüşme ya da bağlantı moduna geçerek yakın çevreleriyle gerçek ilişkilerini koparmaktadırlar. Bu kuşak katılımcıları zaman tüketimi konusunda baskı hissetmektedir:

"Gruplaştırırken yalnızlaştırıyor. Sanal ve sahte. Yüz yüze iletişimden çok farklı, her şey çok yüzeysel" (Y1). "Yanımdaki insandan sıkılmışsam telefona gömülmüşümdür. Sıkıldığım zaman imdat oluyor. Çevrem bana hitap etmiyorsa gömülürüm. Bireyselleşmeyi tercih ederim" (Y2). "Albenisine takılıyorum. Zamanımı tüketiyor. Gruplar var ama dahil olmak istemiyorum ama çıkamıyorum da" (Y3). "Bulunmamak isterim bazen, duymamak işime gelir" (Y4). "Ailem sevmediğim bir şeyi tv'de izlerken imdadıma yetișir" (Y4).

Z kuşağı temsilcileri akıllı telefonların baskı aracı niteliğini taşıdığını belirmektedir:

"Baskı aracı olabiliyor" (Z1, Z2, Z3). "Bireyselleşme konusunda daha çok diğerlerine bağımlı yapar. Bir süre sonra diğerlerinin ne yaptığını öğrenme ihtiyacı hissediyorsun. Yine eksik kalmamak ihtiyacı bu. Beni gerçeklikten koparamaz. Bununla gerçeğin içinde olduğumu hissediyorum" (Z1). "Arkadaşlarım orada bahis oynuyor, sürekli maç takip ediyorlar. Sosyal açıdan gerçek hayatı kısıtlıyor" (Z2).

Mekân-temelli bağlantıya karşıt olarak, yeni iletişim teknolojileri yoluyla birey bireye bağlantıya yönelik bir eğilim görülmektedir (Otani 1999; Wellman ve Potter, 1999). Bireyselleştirme konusunda X kuşağı temsilcileri farklı bir bakış açısına sahiptir; akıllı telefonları etkin ve verimli kullanmayı bilmeyenlerin bireyselleşeceği kanaatindedir:

"Bu cihazları etkin ve verimli kullanamayanları bireyselleștirir. Kullanmayı bilmiyorsan kölesi olursun. 'Olmazsa olmaz, ölürüm, biterim' derler, ama onların kullandıkları sadece sosyalleşme yani Facebook, WhatsApp ya da Instagram'dır. Elinin altındaki 
sistemi, veri elde etmeyi bilmiyorlar. Birçok şeyi elde edebilecekken başka yerlerde zaman öldürüyorlar. Bunların çoğunu gençler oluşturuyor" (X2). "Bireyselleștiriyor mutlaka ama katı değilim. Daha önce de bireyselleşiyorduk. Mesela, kitap okuyorduk, aynı şeyi şimdi ekrandan yapıyorum. Sonuçta yine aynı eylemi yapıyorum" (X3).

Castells vd. (2007) yer ve zamanın yapılanma sürecini 'mekân akışı' ve 'belirsiz zaman' olarak tanımlamaktadır ve mekânın kişiselleştirildiği, yani belirli zamanda mekân akışında yeni 'mekanların var olduğu' șeklinde anlamlandırmaktadır. Genç kuşakların ifadeleri bu durumu desteklemektedir:

\begin{abstract}
"Kız arkadaşım uzakta öğretmen onunla anlık iletişim kurabiliyoruz. Görüntülü konuşup fotoğraf atıyoruz. Mesela ben onun okuluna gitmedim, ama nasıl bir yer olduğunu akıllı telefon sayesinde biliyorum. Hatta yeni eve çıktı; evin odalarını biliyorum. Mekân sınırlandırmasını en aza indirmiş bir şeydir akıllı telefon bence. Mekânsızlaştık diyebiliriz" (Y5).
\end{abstract}

\title{
Sonuç ve Tartışma
}

$\mathrm{Bu}$ çalışma, akıllı telefonların enstrümantal boyutta ve mobil iletişimin entegrasyonuyla insanların sosyal hayatında yarattığı değişimleri ortaya çıkarmak, bu değişimleri değerlendirmektedir. Y ve Z kuşağında iletişim aracı boyutuna cihazın tesiri iletişime eklenmektedir. Bu kuşaklarda benliğini sosyal sunumunda cihazın tesiri görülmektedir. Gençlerde teknolojinin benimsenmesi kendilerine has özel yaşam aşamalarında farklılık gösterebilmektedir. Mobil telefonlar ergen gençler için (X) mantıksal bir aygıt konumundadır. Akranlarıyla iletişimlerinde ya da kendi ailelerinden belli bir derecede uzaklaşmayı başka bir deyişle özgür olmayı arzulayan bir durumdalar. Bu aygıt onlar için hayati derecede tesirlidir hatta yaşamlarıdır. Mobil telefon ile bütünleşiktirler; mobil telefon yokken nasıl bir koordinasyon yapılabildiğini tasavvur edememektedirler. $\mathrm{Bu}$ nedenle onlara göre telefon öncesi hayat tasavvur edilemez zorluktadır. Mobil telefon kullanımı basamakları olan bir beceridir, herkes uzman olamaz. Bu konuda becerisi yüksek olanlar bu yeteneklerinin takdir edilmesi beklentisi içerisindedir. Bu beklentilerini çoğu zaman dijital hediyeler ve bunların aracılığında şekillenen benliklerini sunarak, sahneleyerek giderme eğilimindedirler. Kendi yaşıtları ile daha özgür kalabildikleri sanal ortamları aktif olarak kullanmaktadırlar. Arkadaşlık biçimleri, farklıdır. Bir eylemde bulunurken satranç oyunu gibi birkaç adım ötesini hesaplama eğilimindedirler. İşlerine yarayan uygulamaları arayıp bularak niteliklerini en son sınırına kadar öğrenmekte hatta en zayıf noktalarını ortaya çıkarma uğraşısında bulunmaktadır. Zaman sınırlamasının kendilerine bırakılması gerektiği ve kendi kontrollerini sağlayabilecekleri görüşündedirler.

Gençler mobil telefonlar sembolik bir ifade biçimi olarak kullanılmakta, sosyal statüyü ve aidiyet temsilini cep telefonunun fiziksel görünümüne yüklemektedirler. Genç kuşak (Y) için mobil telefonlar el-ayak gibi bir vücut uzantısıdır. Dolayısıyla genç kuşağın davranıșsal normlarının bir sembolü haline gelmiştir (apparatgeist). Sahip olmamak bir dezavantaj bir eksikliktir. Telefon edinimi bu kuşak için de şekillendirdikleri benliklerini sunma aracı işlevini üstlenmektedir. Bu kuşaktaki katılımcıların her bir mobil aygıtın sorun çıkarıcı değil sorun çözücü olduğu konusunda hem fikirdirler. Ancak zaman tüketimi konusunda kaygı halinde ve bu durumla başa çıkmak, zamanı kontrol altında tutma çabası içerisindedirler. Gerçek yaşamlarındaki sıkıntılı ortamlardan uzaklaşmak için mobil aygıtlar sığınılacak ortam oluşturmaktadır. Telefonun enstrümantal tesiri ya da baskısı kontrol altında tutulabilir. 
Yetişkin kuşak (X) için akıllı telefonlar diğer kuşaklar kadar hayati önem taşımamakla birlikte sorun çözmede tesirlidir. Telefon ediniminin statü ile ilişkisi yoktur. Telefon edinimindeki kıstasları, işine yarayan, amacına uygun, etkin ve verimli kullanabilecekleri özellikleri taşımasıdır. Katılımcılar görüşme sonunda akıllı telefonların vazgeçilmez olduğu fikrini benimsemişlerdir. Gençlere dair özgürlüklerin kısıtlandığı ortak görüşü bu kuşak tarafından belirtilmektedir.

Bütün kuşaklar telefon edinmenin ekonomik seviyenin bir göstergesi olmadığını ve telefonun belli birkaç özelliğinin dışındaki teknolojik özelliklerinin bilincinde olmadan telefon edinen ve kullanan bir kitlenin olduğu ortak fikrine sahiptir. Eğlendirici ve keyif verici işlevinin olması diğer bir ortak yaklaşımdır. Z kuşağı temsilcileri yetişkin kuşağın öğreticisi konumundadır ve onlara göre yetişkin kuşak diğer kuşaklara göre teknolojiye adaptasyon sorunu yaşamaktadır. Sosyal etkileşim birincil düzeydeki ilişkilerde ilk sırayı almaktadır. İkincil düzeydeki ilişkilerde $\mathrm{x}$ kuşağı ve z kuşağı arasında sosyal etkileşim ve koordinasyon seçenekleri yer değiştirmektedir. Üçüncül düzey ilişkilerde güvenlik bütün kuşaklar arasında önceliklidir. Yani örneklemdeki temsilcilerde hiç yüz yüze gelinmemiş ve sadece bir iletişim sistemi sayesinde ilişki kurmak zorunda kalındığında güvenilirlik ön plana çıkmaktadır. Mobil iletişim ve güvenirlik konusunda daha doyurucu bilgiler, başka temsilcilerin katılımı ve daha geniş sorgulamalar içeren başka araștırmalarla daha da geliştirilebilir.

Genç ve yetişkin kuşaklarda 'akıllı telefon bağımlılığı' tehlikesi diğer konuları geride bırakmaktadır. Yetişkinlerin (X) her biri görüşmeye akıllı telefonsuz yaşayabileceklerini, bağımlı olmadıklarını belirterek başlamakta, ancak görüşme sonunda hayatlarına çok fazla gömüldüğünü fark ettiklerini belirtmektedirler. Genç kuşak (Y) görüşme başlangıcında telefon kullanımlarını sınırlama mücadelesi içinde olduklarını belirtmektedir. Z kuşağı temsilcileri ise bağımlılık konusunu dile hiç getirmemektedir. Genç kuşaklar akıllı telefonlar vasıtasıyla bireyselleșmeyi bazen özellikle kendileri istemektedir. Bunda sıkıntılı ortamlardan uzaklaşma fikri etkili olmaktadır. Dolayısıyla yeni iletişim teknolojilerinin bireyselleştirmedeki rolü belirgindir. Mekân akışı ve belirsiz zaman savı desteklenmektedir. Mikro ve hiper koordinasyonda kuşaklar arasında farklılıklar mevcuttur.

Özetle akıllı telefonlar iletişim tarzlarını ve yaygın olarak insanların davranış şekillerini değiştirmektedir. 21. Yüzyılda hayatımıza giren teknolojik donanımlar ve cep telefonları yaşam içerisinde 'hayati bir organ' rolünü üstlenmiştir. Bu noktada "Tele-koza" (Tele-cocooning) etkisinden bahsedilebilir (Ichiyo Habuchi, 2005). $\mathrm{Bu}$ etki insan ve bilgisayar etkileşimini, yani bir insanın başka bir insanla fiziksel temasının olmadığı bir iletişimi tanımlamaktadır. Çoğu insan günümüzde özellikle teknolojinin daha etkin formlarını kullanmayı seçmektedir. Bu teknolojik formlar iletişimde daha hızlı ve daha verimli yollar oluşturulmasına izin vermektedir. İletişim artık, küçük hacimli samimi gruplarla kendi bakış açlarının yansıtıldığı ya da inşa edildiği sürece dönüșmektedir.

\section{Kaynakça}

Aktaş, C. ve Çaycı, B. (2013). "Yeni Enformasyon ve İletişim Teknolojilerinin Sosyal Hayattaki Rolü". https://www.academia.edu/ (Erişim tarihi: 10.05.2018).

Bayraktutan, F. (2005). Aile İçi İliş̧kiler Açısından İnternet Kullanımı. Yayınlanmamış Yüksek Lisans Tezi, İstanbul Üniversitesi, İstanbul. 
Bookchin, M. (1996). Ekolojik Bir Topluma Doğru. Abdullah Yılmaz (Çev.). İstanbul: Ayrıntı Yayınları.

Bozkurt, H., Şahin, S. ve Zoroğlu, S. (2016). İnternet Bağımlılığı: Güncel Bir Gözden Geçirme. Çağdaş Tıp Dergisi 6;6 (3), 235-247.

Calhoun, C. (1987) Computer Technology, Large Scale Social Interaction and The Local Community. Urban Affairs Quarterly, 22 (2), 329-349.

Campbell, S. W. and Park Y. J. (2008). Social Implications of Mobile Telephony: The Rise of Personal Communication Society, Sociology Compass, 2/2, 371-387.

Campbell, S. W. and Kelley, M. (2006). Mobile Phone Use in AA Networks: An Exploratory Study. Journal of Applied Communication Research 34, 191-208.

Campbell, S. W. and Russo, T. C. (2003). The Social Construction of Mobile Telephony: An Application of the Social Influence Model to Perceptions and Uses of Mobile Phones in Personal Communication Networks. Communication Monographs 70, 317-34.

Castells, M. (2007). Communication, Power and Counter-power in the Network Society. International Journal of Communication 1, 238-66. http://ijoc.org/ ojs/index.php/ijoc/article/view/46 (Erişim tarihi 11.05. 2018).

Castells, M. (2008). Ağ Toplumunun Yükselişi. 1. Cilt, 2. Baskı. Ebru Kılıç (Çev.). İstanbul: Bilgi Üniversitesi Yayınları.

Esen, E. ve Siyez, D. (2011). Ergenlerde İnternet Bağımlılığını Yordayan Psikososyal Değişkenlerin İncelenmesi, Türk psikolojik Danışma ve Rehberlik Dergisi. 4 (36), 127-138.

Fortunati, L. (2003). The Mobile Phone and Self-presentation. Paper presented at the Front Stage/Back Stage: Mobile Communication and the Renegotiation of the Social Sphere Conference, Grimstad, Norway.

Goffman E (1959) The Presentation of Self in Everyday Life. New York: Doubleday Publishing.

Hammill, G. (2005). Mixing and Managing four generations of Employees. MDU Magazine, Winter/Spring, www.fdu.edu/newspubs/magazine/05ws/ generations.htm. (Erişim tarihi 11.03. 2018).

Holstein, J.A, Gubrium, J.F. (1997). Active Interviewing. D. Silverman (Ed.), Qualtitative research: Theory, Method and Practise, 113-129. London: Sage Publications.

Hulme, M. and Sue, P. (2002). Me, My Phone, and I: The Role of The Mobile Phone. Proceedings of CHI Workshop on Mobile Communications. Seattle, Washington.

Howe, N. \& W. Strauss. (1992). Generations. Quill Publications.

Johnsen, T.E. (2003) 'The Social Context of the Mobile Phone Use of Norwegian Teens', in J. Katz (ed.) Machines that Become Us: The Social context of Communication Technology, 161-70. New Brunswick, NJ: Transaction Publishers.

Karagülle, A. E. (2014). Ağ toplumunda sosyalleșme ve yabancılaşma. The Turkish Online Journal of Design, Art and Communication-TOJDAC, 4 (1), 1-9.

Katz, J. E., \& Aakhus, M. A. (2002). Perpetual Contact: Mobile Communication, Private Talk, Public Performance. Cambridge, UK: Cambridge University Press. 
Kümbetoğlu, B. (2005). Sosyolojide ve Antropolojide Niteliksel Yöntem ve Araştırma. İstanbul: Bağlam Yayınları

Leung, L. (2004). Net-Generation Attributes and Seductive Properties of the Internet as Predictors of Online Activities and Internet Addiction. Cyberpsychology \& Behavior, 7 (3).

Lai, C. (2007). Sociotechnical Capital Accrues to the Younger Generation-Use of Mobile Phones, IM and Online Social Networking Sites. San Francisco, CA: Paper presented at The International Communication Association Preconference, Mobile Communication: Bringing Us Together or Tearing Us Apart?

Leung, Louis and Ran Wei (2000). More Than Just Talk on the Move: A Use-andGratification Study of the Cellular Phone.Journalism and Mass Communication Quarterly 77: 308-20.

Licoppe, Christian (2003). Two Modes of Maintaining Interpersonal Relations through Telephone: From the Domestic to the Mobile Phone, 171-86. In Machines That Become Us: The Social Context of Communication Technology, ed. by E. Katz James. New Brunswick, NJ: Transaction Publishers.

Ling, R. Yttri, B. (1999). Nobody Sits at Home and Waits for the Telephone to Ring: Micro and Hyper-Coordination through the Use of the Mobile Phone (Report 30/99). Kjeller, Norway: Telenor Research and Development.

Ling R and Yttri B (2002) Hyper-coordination via Mobil Phone in Norway. New York: Cambridge University Press, 139-169. http://citeseerx.ist.psu.edu/viewdoc/ download?doi=10.1.1.180.1209\&rep=rep1\&type=pdf (Erişim tarihi 15.05. 2018).

Ling, R. (2004). The Mobile Connection. San Francisco, CA: Elsevier.

Love, S. and Kewley, J. (2005). Does Personality Affect Peoples' AttitudeTowards Mobile Phone Use in Public Places?, 273-84 in Mobile Communications: ReNegotiation of the Social Sphere, ed. by Ling R. and Pedersen P. E. London, UK: Springer-Verlag.

McLuhan, M. (1962). The Gutenberg Galaxy: The Making of Typographic Man. Toronto, ON: University of Toronto Press.

McLuhan, M. (1964). Understanding Media: The Extensions of Man. New York, NY: New American Library.

Miyata, K. Wellman, B. and Boase, J. (2005). The Wired-and Wireless-Japanese: Webphones, PCs and Social Networks, 427-50 in Mobile Communications: ReNegotiation of the Social Sphere, ed. by Ling R. and Pedersen, P. E. London, UK: Springer-Verlag.

Murtagh, G. M. (2001). Seeing the "Rules": Preliminary Observations of Action, Interaction and Mobile Phone Use, 81- 91 in Wireless World: Social and Interactional Aspects of the Mobile Age, ed. by Brown, B. Green, N. and Harper R. London, UK: Springer-Verlag.

Paragas, F. (2005). Being Mobile with the Mobile: Cellular Telephony and Renegotiations of Public Transport as Public Sphere, 113-30 in Mobile Communications: Re-Negotiation of the Social Sphere, ed. by Ling R. and Pedersen, P. E. London, UK: Springer-Verlag. 
Park, W. K. (2005). Mobile Phone Addiction, 253-72 in Mobile Communications: Renegotiation of the Social Sphere, ed. by Ling R. and Pedersen, P. E. London, UK: Springer-Verlag.

Patton, Q. M. (1990). Qualitative Evaluation an Research Methods (2nd ed). London: Sage Pub.

Simkova, B. \& Cincera, J. (2004). Internet Addiction Disorder and Chatting in the Czech Republic. Cyberpsychology \& Behavior, 7 (5).

Skog, B. (2002). Mobiles and the Norwegian Teen: Identity, Gender, and Class, 255-73 in Perpetual Contact: Mobile Communication, Private Talk, Public Performance, edited by James E. Katz and Mark A. Aakhus. Cambridge, UK: Cambridge University Press.

Senbir, H. (2004). Z Son Ínsan mı?, İstanbul: Okuyan Us Yayınları.

Wei, R. and Leung, L. (1999). Blurring Public and Private Behaviors in Public Space: Policy Challenges in the Use and Improper Use of the Cell Phone. Telematics and Informatics 16, 11-26.

Wellman, B. (2001). Physical Place and Cyberplace: The Rise of Personalized Networking, International Journal of Urban and Regional Research, 25, 22752.

Wellman, B. \& Potter S. (1999). The Elements of Personal Community, 49-82 in Networks in the Global Village: Life in Contemporary Communities, ed. by B.Wellman. Boulder, CO: Westview Press.

Williams, S. (2010). Welcome To Generation Z, B\&T Magazine, 60 (2731).

Young, K.S. (2004). Internet Addiction. Am Behav Sci 48, 402-441.

Yıldırım, A. ve Şimsek, H. (1999). Sosyal Bilimlerde Nitel Araştırma Yöntemleri. Ankara: Seçkin Yayınevi. 